\title{
Effectiveness of Tax Incentives of Hard-To-Recover Oil Reserve Development
}

\author{
I. V. Sharf, M. P. Ivanova, I. V. Filimonova
}

\begin{abstract}
The present-day stage of the world hydrocarbon market development is characterized by the growing share of oil and gas production from the fields related to hard-to-recover reserves in terms of different criteria, which is a consequence of technological breakthrough in the USA. The strategic task of Russian oil and gas sector is to intensify the development of such fields with governmental support in the form of tax incentives. The goal of this research is to consider dynamics of oil production from the fields related to Bazhenov, Abalak, Domanic, and Khadumsk geological formations with enormous hydrocarbon potential thanks to tax incentives. The research method used is statistical analysis. The research results have shown the effectiveness of tax incentives, but due to absence of native development technologies, the effectiveness of incentives is evened, which requires different approaches to the tax incentive system.
\end{abstract}

Index Terms: hard-to-recover reserves; oil; regions; tax incentives; technologies.

\section{INTRODUCTION}

In Russia oil and gas sector is the basis for economy being an important source of income contributing to the country budget. According to the data of the RF Ministry of Natural Resources and Ecology, the proved reserves of NGL amounted 80 barrels in Russia as of 1.01.2018 (the 8th place in the world) [1], whereas daily production reached $11 \mathrm{mln}$. barrels (14\% of the world production). In 2017 crude oil production including NGL amounted $546.7 \mathrm{mln}$ t. In $2018-$ $555.9 \mathrm{mln}$ t. Of total gain more than a half $(+5.0 \mathrm{mln} \mathrm{t},+13,5$ $\%$ ) was produced from the new fields with operation periods up to 5 years [2]. However, most of the fields providing major amount of oil extraction are currently near-depleted, which means a significant decline in oil production.

About $70 \%$ of the Russian NGL resource base concentrate in 11 unconventional and 179 large multi-horizon formations mostly located in the territory of Western-Siberian oil-and-gas basin [2]. To minimize the losses connected with depletion of large fields and decrease in NGL production, it is necessary to start developing NLG hard-to-recover reserves in a commercially effective manner.

At present, $65 \%$ of hydrocarbon reserves belong to the hard-to-recover class of which $34 \%$ are reserves found more than 20 years ago but not developed, 26\% are reserves $(\mathrm{C} 1+\mathrm{C} 2$ class) discovered within recent 20 years [2], $4 \%$ are

Revised Manuscript Received on July 20, 2019.

I. V. Sharf, School of Earth Sciences \& Engineering, Tomsk Polytechnic University, Tomsk, Russia.

M. P. Ivanova, School of Earth Sciences \& Engineering, Tomsk Polytechnic University, Tomsk, Russia.

I. V. Filimonova, Department of economics, Novosibirsk State University, Novosibirsk, Russia. hard-to recover reserves of developed fields. They are not being developed due to lack of proper technologies as well as economic unprofitability at present-day pricing terms of the world market.

The goal of this paper is to analyze the effectiveness of tax incentives in hard-to-recover oil field development.

\section{MATERIALS AND METHODS}

There are different approaches towards the term "hard-to-recover oil reserves" in the literature. In this paper the authors attempt to accomplish the set tasks based on the tax legislation which peculiarities with respect to hard-to-recover oil reserves have been considered in works of Sharf I.V. [3], [4], Grinkevich L.S. [3], [4] and principal trends in government development strategy of oil-and-gas industry taking into account their development in works of Filimonova I.V. [5], [6]. Let us consider incentives regarding oil with specific properties.

From the standpoint of hydrocarbon resources quality there are oils with abnormal physical and chemical properties: heavy (with density $\rho \geq 0.88 \mathrm{~g} / \mathrm{cm}^{3}$ ); high-viscosity with $\mu \geq 35 \mathrm{~mm}^{2} / \mathrm{s}$; sour; paraffin; tarry; with high (more than $500 \mathrm{~m} / \mathrm{t}$ ) or low (less than $200 \mathrm{~m} / \mathrm{t}$ ) gas-saturation; with more than $5 \%$ of aggressive compounds (hydrogen sulfide, carbon dioxide) in free and (or) dissolved gas [7].

Besides, Besides, oil properties vary owing to historical and geological conditions within a region. According to the data of Petroleum Chemistry Institute (Siberian Branch, Russian Academy of Science), the types of oil mentioned above are conventional for many fields in the world.

Geological history of Volga-Ural petroleum province has conditioned formation of commercial reserves in horizons of Devonian, Carbomic, and Perm periods. Oil seepages are found in rocks of Riphean-Vendian age. In this case recoverable reserves of heavy oil are estimated as $\geq 660 \mathrm{mln}$ $t$., which are mainly located in small deposits with reserves of $\leq 1 \mathrm{mln}$. $t$, but only $7 \%$ and referred to large-size fields. $20 \%$ of total production is production of heavy oil [8].

In Udmurtia there is the largest share of heavy oil among all areas of Volga-Ural petroleum industry $-83 \%$. Physical and chemical properties of oils from Udmurtia fields are characterized by the following parameters:
a) density $851-968 \mathrm{~kg} / \mathrm{m}$
b) oil viscosity at $20^{\circ} \mathrm{C} 7.7-5103 \mathrm{mPa}-\mathrm{s}$
c) sulfur content $1.57-3.22 \%$
d) paraffin content $0.5-5.6 \%$
e) high-molecular 
component content: $\operatorname{tar} 10.7-24.7 \%$, asphaltene $1.2-5.5 \%$ [9].

The oil of Bashkortostan Republic is characterized by high sulfur content (more than $2 \% \mathrm{~S}$ ) and oil viscosity (more than $30 \mathrm{mPa}-\mathrm{s}$ ). In terms of density, oil is referred to medium class $\left(0.87-0.9 \mathrm{~g} / \mathrm{cm}^{3} ; 67 \%\right)$ and is estimated as heavy (more than $0.9 \mathrm{~g} / \mathrm{cm}^{3}, 16.8 \%$ ). The major part (about $60 \%$ ) of hard-to-recover oil reserves is concentrated in terrigenious rocks, whereas the other part includes complex-structure carbonate reservoirs. The actual reserves of high-viscous oil (more than $30 \mathrm{mPa}-\mathrm{s}$ ) amount $59.7 \mathrm{mln} \mathrm{t}$ (15.3\%). Nearly 28 $\%$ of oil reserves are located in low-permeable reservoirs (less than $0.05 \mathrm{mkm}^{2}$ ). Paraffin content that influences oil density and viscosity ranges within $1.5-6 \%$.

In the Tatarstan Republic bitumens of Perm formations are referred to hard-to-recover oil which besides their high viscosity are characterized by high concentration of sulfur (3.7-7\%), oils (5.8-88.0\%), tars (8.7-57.0\%), asphaltene (3.3-61.0\%). Reserves of such oil are estimated as 7-8.7 bln. t, 1.5-2 bln of which are possible to recover in the short-term.

The share of super-viscous oil in developed hard-to-recover fields of $\mathrm{ABC} 1+\mathrm{C} 2$ class amounts $21 \%$ [10]. As for a type of geologic formation, there are oil fields referred to Bazhenov, Abalak, Domanic, and Khadumsk pay zones according to the tax legislation which are to be developed with tax incentives.

Bazhenov suite is confined by Upper-Jurassic deposits and has a rich source, its occurrence area is more than $1 \mathrm{mln} \mathrm{km} 2$ in Western Siberian petroleum province. Administratively, it is located within Khanty-Mansi (KMAA) and Eastern and Central part of Yamal-Nenets Autonomous Areas, Tomsk Oblast. Bazhenov formation is composed of bituminous mudstone (a source rock), where organic matter content reaches $17 \%$.

Khadumsk suite confined by deposits of Lower and Middle Oligocene is represented in the territories of Pre-Caucasian and North Caucasus. Its organic matter content amounts about $2 \%$ on average.

Domanic suite is represented nearly everywhere in the Eastern European platform within Timan-Pechora and Volga-Ural petroleum basins. The formation is composed of argillous carbonaceous rocks of Upper-Devonian age. Domanic formation contains about $5 \%$ of organic matter on average.

Recoverable oil reserves of $\mathrm{ABC} 1+\mathrm{C} 2$ class of Bazhenov formation registered in the State Balance Sheet amount about $530 \mathrm{mln}$. t. [10]. There are oil reserves in more than 70 fields in deposits of Bazhenov formation.

According to Rosneft data, proved oil reserves of Khadumsk formation amount only about $11 \mathrm{mln}$. t. and the production is nearly stopped.

In Domanic deposits around 10 oil fields are discovered with total amount of recoverable oil reserves about $27 \mathrm{mln}$. t. [10].

On the whole, the given fields have been poorly studied yet, therefore, significant build-up of reserves is expected with growth of geologic exploration of these formations, which are referred to oil source rock from the organic theory point of view.

\section{RESULTS}

Development of hard-to-recover oil reserves is encouraged by tax incentives. Crude oil recovery from Bazhenov, Abalak, Domanic, and Khadumsk productive formations is exempt from taxes. Oil of $10000 \mathrm{mPas}$ viscosity and more is produced at $0 \%$ tax rate.

It is necessary to indicate the state strategy in production of oil distinguished by viscosity rate:

- low viscous (to $10 \mathrm{mPa}-\mathrm{s}$ );

- higher than average viscosity (to $200 \mathrm{mPa}-\mathrm{s}$ );

- high viscous (1000 $\mathrm{mPa}-\mathrm{s})$;

- super-viscous (to $10000 \mathrm{mPa}-\mathrm{s}$ );

- natural bitumen (more than $10000 \mathrm{mPa}-\mathrm{s}$ ).

Thus, beginning from 01.04.2007 $0 \%$ preferential royalty fields (PRF) have been granted for viscous oil produced from the sites containing oil of more than $200 \mathrm{mPa}$-s viscosity (in reservoir) [11]. Since 01.01.2015 reduced tax rate of PRF has been imposed for the oil production with the $\mathrm{Kkan}=0$ coefficient in the PRF tax rate calculation formula. In this case a taxpayer may apply a zero rate (paras. 9 p. 1 Art. 342 RF TC) for super-viscous oil production from the sites containing oil of $10000 \mathrm{mPa}-\mathrm{s}$ and more viscosity (in reservoir) [11]. Thus, in our opinion, such a transformation is an example of the RF government's consistent policy to encourage development and implementation of advanced technologies and resource-innovative approaches.

According to the data of the Federal Tax Service of the Russian Federation [12], super-viscous oil production is increasing. For example, from 2015 to 2017 oil production taxable with $0 \%$ tax rate has grown by $220 \%$, from 1191 mln. $\mathrm{t}$ in 2015 to $3822 \mathrm{mln}$. $\mathrm{t}$ in 2017 (Fig.1).

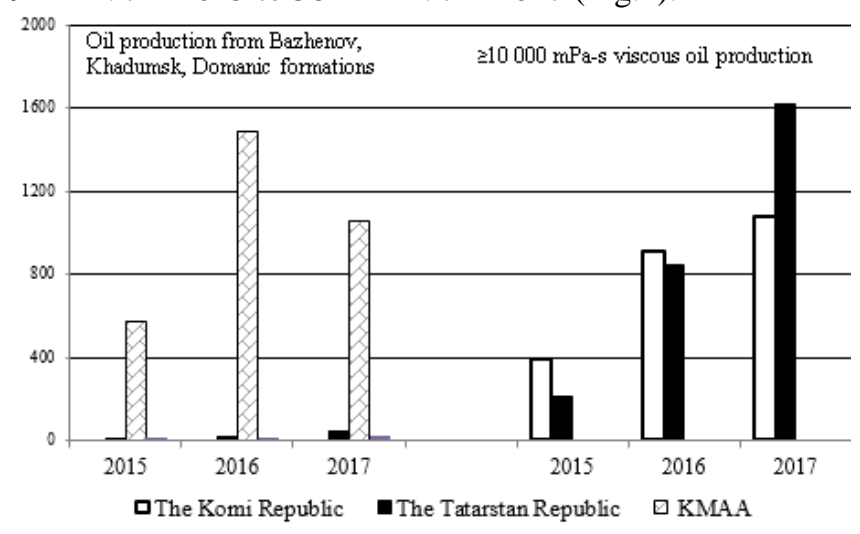

Fig. 1: Volume of exempt oil production in the RF regions

The question now arises of whether these tax incentives are effective. For example, at Ashalchinskoye oil field "10-10-10" mode is used, the essence of which consists in the fact that since 2006 a $0 \%$ tax rate is used for super-viscous oil, whereas since the mid of 2012 during 10 years a reduced tax rate has been used for export tax of $10 \%$ of regular one. These measures in addition to property tax privilege have made the super-viscous oil production commercial [13]. The commercial value of the project consists in development and implementation of domestic technologies based on three couples of dual head horizontal wells, 
unique in the world practice, as well as simulation of operation conditions. It results in increasing super-viscous oil production up to $1.6 \mathrm{mln}$. $\mathrm{t} / \mathrm{g}$, providing about 1.2 thous. employment opportunities, income build-up of 446 bln. rubs., GDP growth of 335 bln. rubs. in related industries. Moreover, tax revenues from oil production were estimated at $88 \mathrm{bln}$. rubs.

Development of super-viscous oil fields is of high-cost because of necessity to construct horizontal wells (2.5 times) and oilfield facilities (3.5 times) at the initial stage of a field life, whereas at mature fields the operating and support costs are high and payable within a short time at the appropriate oil prices. Low prices have been a cause for freezing the project of Mordovo-Karmalskoye field development since 2011.

In Tomsk Oblast there is a negative trend in the form of absolute decrease in oil production from Bazhenov formation - from 0.003 mln.t. in 2015 to zero in 2017. It is worth noting a growing production in Stavropol Territory from Khadumsk formations that has grown from $6 \mathrm{mln}$. t. to $18 \mathrm{mln}$. t. over three years.

It should be noted that in other Russian Federation regions there is a zero production, particularly in Samara Oblast, Perm Krai, the Udmurt Republic, and Mordovia Republic, though Domanic formations are common there.

Thus, the effectiveness of tax incentives in oil production from the hard-to-recover fields is obvious. Though it is hampered by the price dynamics in the oil world market, nevertheless, there are still some issues to be discussed

\section{DISCUSSION}

However, despite the positive dynamics of oil production in the RF regions considered above and effectiveness of existing incentive policy, there are some engineering and tax problems, which define oil production costs and, consequently, competitiveness of the Russian oil companies in the world market, which is clearly seen from the production dynamics in Tomsk Oblast conditioned by quality characteristics of Bazhenov formation: abnormally high reservoir pressure and temperature and insignificant formation thickness [14] that results in demand for thermobaric conditions both at core recovery in geological prospecting and at production, hence, improvement of technologies applied in KMAA is rather urgent.

The production technologies of super-viscous oil and natural bitumen are determined by geological conditions, physical and chemical properties of reservoir fluid and other parameters. The technologies currently used are mining, cold, and warm production methods. The first technology is used by Lukoil Company at Yaregskoye oil field in the Komi Republic which is one of the priorities in the industry, as it is expected to increase the production over ten years 4 times more due to mining intensification. In 2014 the production grew by $18.6 \%$ [15]. Cold production methods were borrowed from abroad (Canada, Venezuela) and are at the development stage. Furthermore, sanctions can significantly influence the durability of the stage, since application of the technology requires drilling of two horizontal wells and solvent injection in stratum which liquifies oil by gravity drainage. Technology of thermal treatment was used at

\section{Ashalchinskoye oil field (Tatarstan).}

Regardless of incentives, oil production from Khadumsk formation is not underway due to lack of technologies. Based on the international experience in hydrocarbon shale deposit development, prospecting, exploration, and development of anticipated unconventional hydrocarbon deposits in Khadumsk formation, directional and horizontal wells are recommended to be drilled. Horizontal drilling provides more contact to a reservoir formation than a vertical well. Another technological approach to cost-effective development of hard-to-recover oil reserves is hydraulic fracturing which implies injection of fluid into shale reservoir under high pressure to make fractures or cracks in target formation. This process enables hydrocarbon inflow from shale formation to the well in commercial volumes [16].

In spite of prospective resources of Domanic formations, the volume of exempt oil production amounts 0 thous. tons [12] (Samara Oblast, Perm Krai, the Udmurt Republic, and Mordovia Republic), as a few companies have necessary technologies of oil development of hard-to-recover fields.

Thus, the major volume of oil production in Russia with zero tax rate includes heavy high viscous oils located in the areas of the Komi and Tatarstan Republics as well as hard-to-recover reserves of Stavropol Territory (Khadumsk formation), Khanty-Mansi Autonomous Area (Abalak, Bazhenov formations) oil of Domanic formations in Tatarstan.

At present one can distinguish two relevant trends in production technology development of hard-to-recover reserves. Firstly, pilot testing of existing technologies to adapt them to complicated geologic conditions, secondly, development of innovative production technologies.

The replacement problems related to definite regions have contributed to setting up different strategic programmes. For example, in the Tatarstan Republic The Strategy for Development of Energy Sector of the Tatarstan Republic until 2030 was approved [17], which is aimed at maximal effective use of fuel and energy resources taking into account such characteristics of mineral resource territory as reserves depletion of "easy-to-recover" oil and development of new production technologies.

Thanks to the Programme for the Development of Reserves of Heavy Oils and Bitumen in the Republic of Tatarstan until 2020 and a number of other natural reserves development programmes [18], as well as test sites built at Mordovo-Karmalskoye and Ashalchinskoye oil fields in 1978, where the technologies of in-situ combustion were tested using thermal gas generator, high-frequency electromagnetic field, steam, changes of filtration flows, bitumen extraction by means of low-temperature oxidation and other technologies [19], it became possible to produce 1.5-2.0 bln. t. of oil in the short-term.

"Bazhenov" research ground was built in KMAA. The programme is intended to be realized in 4 stages for a potentially indefinite long period: 
1) building of a detailed geological-geophysical model of Bazhenov and Abalak suites;

2) development of a well network to test and pilot new technologies;

3) horizontal well drilling;

4) implementation of new tested technologies.

Moreover, the add-on income tax came into force. It was based on the add-on income tax from oil production and applied for a number of fields. In this case calculated petroleum revenues are taxable, being reduced by combined value of actual and calculated costs for production in this site. According to the legislative draft, the calculated cost is recognized as calculated export custom duties for oil and gas condensate; calculated costs of oil and gas condensate transportation.

The change-over to the add-on income in future is to increase commercial viability of field and deposit development with hard-to-recover oil and gas reserves, which, in its turn, stimulates oil recovery factor and contributes to the growth of oil production volume and, as a consequence, invites additional investments for petroleum industry.

\section{CONCLUSION}

The analysis performed allows for the following conclusions.

1. Growth of oil production in the world and in Russia in the long-term is connected with production from the fields related to hard-to-recover. The resource potential of hard-to-recover oil reserves is huge, but and technological breakthrough is required to develop this potential.

2. The Governmental policy aimed at production technology development for hard-to-recover oil reserves is realized by means of tax incentives. Their effectiveness is supported by the growth of oil production that allows being competitive for Russian oil-and-gas companies in the world market.

3. Introduction of add-on income tax is an additional impetus for hard-to-recover oil reserve development. However, due to high risk of profit reduction to avoid taxes, this tax is, in authors' opinion, a faulty measure in the condition of strong dependence of the Russian budget system on oil-and-gas income.

4. Hard-to-recover oil reserve tax incentives do not often produce stimulating effect. Moreover, to develop the resource potential there is a need for structural transformations in petroleum industry, an increasing number of innovative companies, and growth of competitiveness.

\section{ACKNOWLEDGEMENT}

The work was supported by the RFBR grant 18-010-00660 A.

\section{REFERENCES}

1. Government Report "On the State and Use of Mineral Resources in the Russian Federation" (2018), available online: http://www.mineral.ru/Analytics/StateReport/index.html, last visit: 15.04.2019 (in Russian)

2. Government Report "On the State and Use of Mineral Resources in the Russian Federation in 2016 and 2017', available online:

http://www.mnr.gov.ru/docs/gosudarstvennye_doklady/, last visit: 15.04.2019 (in Russian)

3. Sharf, I.V., Grinkevich, L.S., Economy of Region Assessing the extraction potential of Tomsk region's difficult-to-obtain oil reserves. Vol. 12, No 1, (2016), pp. 201-210.

4. Sharf, I.V., Borzenkova, D.N., Grinkevich, L.S., "Tax incentives as the tool for stimulating hard to recover oil reserves development", Problems of Geology and Subsurface Development: XIX International Scientific Symposium in honor of Academician M.A. Usov, Vol. 27, IOP Conference Series: Earth and Environmental Science, (2015), p. 012079, http://dx.doi:10.1088/1755-1315/27/1/012079

5. Eder, L.V., Filimonova, I.V., Provornaya, I.V., Komarova, A.V., Nikitenko, S.M., "New directions for sustainable development of oil and gas industry of Russia: Innovative strategies, regional smart specializations, public-private partnership", International Multidisciplinary Scientific GeoConference Surveying Geology and Mining Ecology Management, SGEM, Vol. 17, No 15, (2017), pp 365-372, http://dx.doi.org/ 10.5593/sgem2017H/15/S06.046

6. Filimonova, I.V., Eder, L.V., Mishenin, M.V., Mamakhatov, T.M., "Current state and problems of integrated development of minera resources base in Russia", IOP Conference Series: Earth and Environmental Science, Vol. 84, No 1, (2017), p. 012011, http://dx.doi.org/ 10.1088/1755-1315/84/1/012011

7. Yashchenko I.G., "Hard-to-recover oils: physical and chemical properties and ecological effect of their production", Exposition Oil and Gas, No 1, (2014), pp. 30-35 (in Russian)

8. Makarevich V.N., Iskritskaya V.N., Iskritskaya N.I., Bogoslovskiy S.A., "Resource Potential of Heavy Oils in the Russian Federation: Perspectives of Development", Neftegazovaya Geologiya. Teoriya i Praktika, Vol. 5, No 2, (2010), available online: http://www.ngtp.ru/rub/6/29_2010.pdf, last visit: 14.04.2019 (in Russian)

9. Santos R.G., Loh W., Bannwart A.C. and Trevisan O.V., "An overview of heavy oil properties and its recovery and transportation methods", Brazilian Journal of Chemical Engineering, Vol. 31, No. 03, (2014), pp. 571-590, http://dx.doi.org/10.1590/0104-6632.20140313s000018 53

10. Klubkov S., "Stimulation of Hard-to-recover Field Development will Help to Support the Level of Oil Production in Russia", Oil \& Gas Journal, Vol. 7 (95), (2015), pp. 6-11, available online: https://vygon.consulting/pressroom/our-publications/211/ (in Russian)

11. Tax Code of the Russian Federation of 31.07.1998 № 146-FL (from 27.12.2018), available online: http://www.consultant.ru/document/ cons_doc_LAW_19671/, last visit: 20.04.2019 (in Russian)

12. Federal Tax Service of the Russian Federation, available online: https://www.nalog.ru, last visit: 25.04.2019 (in Russian)

13. Khairullin B.Yu., Mamyashev V.G., Romanov Ye.A., Fedortsov V.V., "Innovative Drilling Technologies with Core Sampling and Analysis of High Information", Nedropol'zovaniye XXI vek, No. 1, (2015), pp. 20-25 (in Russian)

14. PJSC Lukoil Oil Company, available online: http://www.lukoil.ru, last visit: 15.04.2019 (in Russian)

15. Yangarbiev N.Sh., Fadeeva N.P., Kozlova Ye.V., Naumchev Yu.V., "Geology and Geochemistry of Khadumsk suite in Pre-Caucasus - as a Potential Source of "Shale" Hydrocarbons", Georesources, Special issue, Part 2, (2017), pp. 208-226, available online: https://geors.ru/media/pdf/21_Kozlova.pdf (in Russian)

16. Strategy of Fuel Energy Complex Development in the Tatarstan Republic for the Period until 2030, available online: https://base.garant.ru/22528313/89300effb84a59912210b23abe10a68 f, last visit: 20.04.2019 (in Russian)

17. Romanov V.G., "On Target Republic Programme of Complex Heavy-Oil Fields and Natural Bitumen Development in the Tatarstan Republic", Georesources, No. 1, (2012), pp. 34-36 (in Russian)

18. Strategy of Fuel Energy Complex Development in the Tatarstan Republic for the Period until 2030. Approved by the Law of the Tatarstan Republic No 41 of 17.06.2015, available online: http://docs.cntd.ru/document/428595087, last visit: 11.04.2019 (in Russian)

19. Maganov N., Ibragimov N., Khisamov R., Zaripov A., Motina L., Mekheev H., "Experience in Development of Heavy Oil Shallow Depth Deposit", Oil\&Gas Journal Russia, (2015), available online:http://ogjrussia.com/uploads/images/Articles/July\%2015/60-63. pdf, last visit: 19.07.2016 (in Russian) 
20. R. J. Vidmar. (1992, August). On the use of atmospheric plasmas as electromagnetic reflectors. IEEE Trans. Plasma Sci. [Online]. 21(3). pp. 876-880. Available: http://www.halcyon.com/pub/journals/21ps 03-vidmar

\section{AUTHORS PROFILE}

I. V. Sharf is a candidate of economic sciences, associate professor of the School of Earth Sciences \& Engineering, Tomsk Polytechnic University. She graduated from Novosibirsk State University in 1991 and Tomsk State University in 2002. The field of scientific research is related to the taxation in oil and gas industry, the reproduction of the mineral resources, analysis of organizational, technical, financial and economic problems of oil and gas industry development in Russia and abroad. The research is presented by numerous articles in journals cited by Higher Attestation Commission, journals from Scopus databases, proceedings of international conferences and symposia (the author of more than 60 scientific papers).

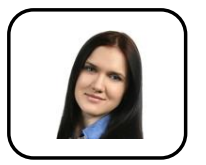

M. P. Ivanova is an assistant of the School of Earth Sciences \& Engineering, Tomsk Polytechnic University. She graduated from Tomsk Polytechnic University in 2004. The field of scientific research is ecological problems and payments for negative effects on the environment in subsoil management. The research is presented by the articles in journals cited by Higher Attestation Commission, journals from Scopus databases, proceedings of international conferences and symposia (the author of more than 30 scientific papers).

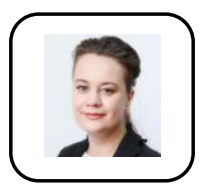

I. V. Filimonova is a Ph.D. (Economics), associate professor, the Head of the department in Novosibirsk State University, the Head of the department of the Centre of Economics and Forecasting of Subsoil Oil and Gas Industry of the Trofimuk Institute of Petroleum Geology and Geophysics, Siberian Branch of the Russian Academy of Sciences (IPGG SB RAS). She graduated from Novosibirsk State University in 2001. She is a specialist in the field of strategic planning and economic-geological evaluation of hydrocarbon reserves and resources. She conducts research on the reproduction of the mineral resource base and evaluation of multi-scale investment projects of the oil and gas industry. Also, she deals with the issues of state regulation and development of the fuel and energy complex of Russia and the Asia-Pacific countries, assesses the prospects for the development of oil and gas processing, petrochemistry, including the assessment of investment opportunity of individual projects. The research is presented by numerous articles in journals cited by Higher Attestation Commission, journals from Scopus databases, proceedings of international conferences and symposia (the author of more than 200 scientific papers). 